\title{
СОДЕРЖАНИЕ
}

А.Г. БЕРЕЖНОЙ, Ю.С. ВИННИК, Ф.П. КАПСАРГИН, Д.М. МАКСЮТОВ ВОЗМОЖНОСТИ ПРОГНОЗИРОВАНИЯ РАЗВИТИЯ ГЕМОРРАГИЧЕСКИХ ОСЛОЖНЕНИЙ У ПАЦИЕНТОВ С МОЧЕКАМЕННОЙ БОЛЕЗНЬЮ В ПОСЛЕОПЕРАЦИОННОМ ПЕРИОДЕ

В.Н. ЕГИЕВ, С.А. КУЛИЕВ, И.В. ЕВСЮКОВА ВЫПОЛНЕНИЕ ТОТАЛЬНОЙ ЭКСТРАПЕРИТОНЕАЛЬНОЙ ПЛАСТИКИ (ТЕР) ПОД ЭПИДУРАЛЬНОЙ АНЕСТЕЗИЕЙ У ПАЦИЕНТОВ С ВЫСОКИМ ОПЕРАЦИОННО-АНЕСТЕЗИОЛОГИЧЕСКИМ РИСКОМ. . .

Ф.Э. АББАСОВ, Р.М. МАХМУДОВ, С.А. МУСАЕВ СРАВНИТЕЛЬНАЯ ОЦЕНКА РЕЗУЛЬТАТОВ ИЗОЛИРОВАННОЙ АКШ И АКШ С ПЛАСТИКОЙ МИТРАЛЬНОГО КЛАПАНА ПУТЬЕМ ЧРЕЗПИЩЕВОДНОЙ ЭХОКГ У БОЛЬНЫХ С ИШЕМИЧЕСКОЙ БОЛЕЗНИ СЕРДЦА

И.Г. МАРИНИЧЕВА, Н.Е. МАНТУРОВА

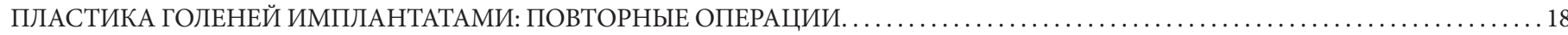

Р.Д. МУСТАФАЕВ, Т.Р. ИБРАГИМОВ, А.А. МАМЕДОВ ОЦЕНКА ЭФФЕКТИВНОСТИ ПРИМЕНЕНИЯ ВЛОК ПРИ ОСТРОМ ХОЛЕЦИСТИТЕ У БОЛЬНЫХ ПОЖИЛОГО ВОЗРАСТА ....... 24

А.К. НИЯЗОВ, А.С. БЕЙШЕНАЛИЕВ, Н.С. ОСМОНБЕКОВА, А.А. НИЯЗОВ ПОСЛЕДСТВИЕ ОСТРОГО ПАНКРЕАТИТА И РАЗВИТИЕ ПСЕВДОКИСТ ПОДЖЕЛУДОЧНОЙ ЖЕЛЕЗЫ ......................30

О.Х. ХАЛИДОВ, И.В. КАРПОВ, А.Н. ГУДКОВ, А.Б. ДЖАДЖИЕВ, Ю.Б. КУНИЦКИЙ, Я.В. КОНДРАТЬЕВ, В.С. ФОМИН ГИГАНТСКАЯ НЕЙРОЭНДОКРИННАЯ ОПУХОЛЬ ПОДЖЕЛУДОЧНОЙ ЖЕЛЕЗЫ. КЛИНИЧЕСКОЕ НАБЛЮДЕНИЕ УСПЕШНОГО ИСПОЛЬЗОВАНИЯ ЛАПАРОСКОПИЧЕСКИХ ТЕХНОЛОГИЙ

М.А. ДАНИЛОВ, С.В. ПОЗДНЯКОВ, А.О. АТРОЩЕНКО, А.О. НИКОЛАЕВА VAAFT (VIDEO-ASSISTEDANALFISTULATREATMENT) В ЛЕЧЕНИИ ПЕРИАНАЛЬНЫХ ПРОЯВЛЕНИЙ БОЛЕЗНИ КРОНА (ЛИТЕРАТУРНЫЙ ОБЗОР)

С.А. РОМАНОВ, Л.Б. ФИЛИМОНОВА, А.В. КУЗНЕЦОВ ЭФФЕКТИВНОСТЬ ПРОФИЛАКТИКИ ЛОКАЛИЗОВАННЫХ ВОСПАЛИТЕЛЬНЫХ ПОРАЖЕНИЙ ТКАНЕЙ ПАРОДОНТА У ЛИЦ МОЛОДОГО ВОЗРАСТА С МЕСТНЫМИ ФАКТОРАМИ РИСКА РАЗВИТИЯ ЗАБОЛЕВАНИЙ.

Н.П. БАЦАЛЕНКО, И.В. РЕШЕТОВ ПРЯМАЯ НЕВРОТИЗАЦИЯ АНАЛЬНОГО НЕОСФИНКТЕРА КАК СПОСОБ УЛУЧШЕНИЯ ЕГО ФУНКЦИИ ...................50

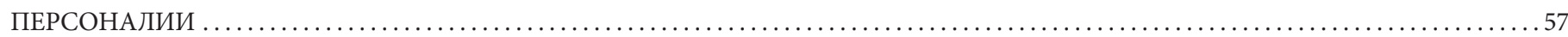

\section{Т.Ш. МОРГОШИЯ}

НАУЧНОЕ МИРОВОЗЗРЕНИЕ АКАДЕМИКА С.Р. МИРОТВОРЦЕВА (1878 - 1949) (К 140-ЛЕТИЮ СО ДНЯ РОЖДЕНИЯ) ............ 58

АЛЕКСАНДР СЕРГЕЕВИЧ ЕРМОЛОВ К 85 -ЛЕТИЮ СО ДНЯ РОЖДЕНИЯ КУРБАНОВ ФАЗИЛЬ САМЕДОВИЧ . 


\section{CONTENTS}

BEREZHNOY A.G., VINNIK YU.S., KAPSARGIN F.P., MAKSUTOV D.M.

POSSIBILITIES OF PREDICTION OF DEVELOPMENT OF HEMORRHAGIC COMPLICATIONS IN PATIENTS WITH

THE UROLITHIASIS IN THE POSTOPERATIVE PERIOD

EGIEV V.N., KULIEV S.A., EVSYUKOVA, I.V. PERFORMING TOTAL EXTRAPERITONEAL PLASTICS (TEP) UNDER EPIDURAL ANESTHESIA IN PATIENTS WITH HIGH OPERATIVE-ANESTHESIOLOGICAL RISK.

ABBASOV F.E., MAKHMUDOV R.M., MUSAEV S.A. COMPARATIVE EVALUATION OF THE RESULTS OF ISOLATED CABG AND CABG WITH MITRAL VALVE PLASTY BY TRANSESOPHAGEAL ECHOCG IN PATIENTS WITH CORONARY HEART DISEASE

MARINICHEVA I.G., MANTUROVA N.E.

CALF PLASTY WITH IMPLANT: SECONDARY SURGERIES .

MUSTAFAEV R.J., IBRAGIMOV T.R., MAMEDOV A.A. EFFECTIVENESS OF INTRAVENOUS LASER BLOOD IRRADIATION FOR TREATING ACUTE CHOLECYSTITIS IN PATIENTS OF ELDERLY AGE

NIYAZOV A.K., BEYSHENALIEV A.S., OSMONBEKOVA N.S., NIYAZOV A.A.

CONSEQUENCES OF ACUTE PANCREATITIS AND DEVELOPMENT OF PSEUDOCYST OF THE PANCREAS. ...

KHALIDOV O.KH., KARPOV I.V., GUDKOV A.N., DJADJIEV A.B., KUNUTZKY YU.B., KONDRATYEV Y.V., FOMIN V.S. GIANT NEURO-ENDOCRINE TUMOR OF THE PANCREAS. CLINICAL OBSERVATION OF SUCCESSFUL USE OF LAPAROSCOPIC TECHNOLOGIES

DANILOV M.A.,POZDNYAKOV S.V., ATROSHCHENKO A.O., NIKOLAEVA A.O.

VAAFT IN THE TREATMENT OF PERIANAL CROHN'S DISEASE (LITERATURE REVIEW) . .

ROMANOV S.A., FILIMONOVA L.B., KUZNETSOV A.V.

THE EFFECTIVENESS OF PREVENTION OF LOCALIZED INFLAMMATORY LESIONS OF PERIODONTAL TISSUES IN YOUNG PEOPLE WITH LOCAL RISK FACTORS FOR THE DEVELOPMENT OF DISEASES

BATSALENKO N.P., RESHETOVI.V.

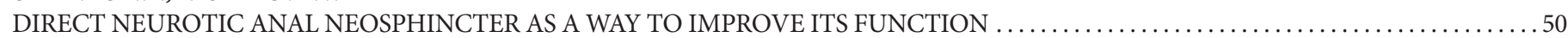

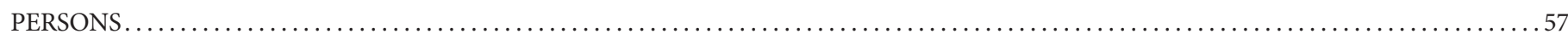

MORGOSHIIA T.SH.

SCIENTIFIC OUTLOOK OF THE ACADEMICIAN S.R. MIROTVORTSEV (1878 - 1949)

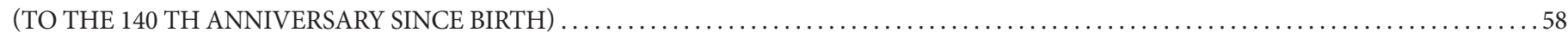

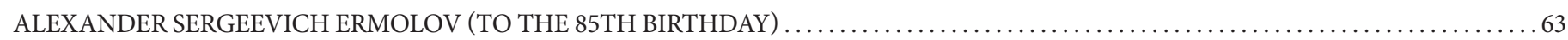

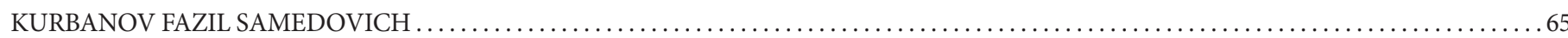

